Proceedings

\title{
Indoor Air Quality in an Auto Repair Shop: A Case Study ${ }^{\dagger}$
}

\author{
Andrzej Gajewski ${ }^{1}$ and Kacper Jermacz ${ }^{2, *}$ \\ 1 Department of HVAC, Bialystok University of Technology, ul. Wiejska 45a, 15-351 Białystok, Poland \\ 2 Students' Scientific Society "Heat Engineer", Bialystok University of Technology, Wiejska Street 45 A, \\ 15-351 Białystok, Poland \\ * Correspondence: k.jermacz@wp.pl; Tel.: +48-608-344-617 \\ † Presented at Innovations-Sustainability-Modernity-Openness Conference (ISMO'19), Bialystok, Poland, \\ 22-23 May 2019.
}

Published: 1 August 2019

\begin{abstract}
The aim of the paper was to conduct an indoor air quality (IAQ) assessment in an auto repair shop, measuring $\mathrm{CO}_{2}$ and $\mathrm{CO}$ concentrations. Carbon monoxide and carbon dioxide concentrations were measured for a week. Two Testo 435-4 gauges were located at head height of an adult person (ca. $170 \mathrm{~cm}$ above the floor) in a room. The $\mathrm{CO}_{2}$ concentration was measured with an IAQ probe, which measures dew point temperature, psychrometer temperature and absolute pressure in indoor air. The second gauge was connected to a CO probe. Measurements were taken every $5 \mathrm{~min}$ and were averaged across an hour. Uncertainties were estimated using square-root combinations of fixed errors and random errors at a 0.05 level of statistical significance. The measurements were conducted from 17 November to 23 November 2018. The following graphs were plotted for carbon dioxide and carbon monoxide: hourly averaged concentration and $8 \mathrm{~h}$ averaged concentration. The results were discussed and compared to Polish, foreign and international standards and recommendations. It was found that the auto shop was in danger of negligence according to Polish law as well as nonfulfillment of healthy recommendations. An exhaust extraction system should be installed.
\end{abstract}

Keywords: indoor air quality; IAQ; carbon monoxide concentration; carbon dioxide concentration; auto repair shop

\section{Introduction}

Hundreds of people in Europe are killed per year by carbon monoxide. $\mathrm{CO}$ is generated by malfunctioning boilers or it infiltrates from garages. In generally, it is a product of incomplete combustion [1]. Moreover, a problem also exists in the garages wherein the concentration $\mathrm{CO}$ is not taken into consideration. The $\mathrm{CO}$ mole fraction exceedance was measured in a multi-car garage by Gładyszewska-Fiedoruk and Nieciecki [2], which inspired the authors of this paper to investigate this problem in other motorisation areas.

Carbon monoxide binds with haemoglobin to form carboxyhaemoglobin $(\mathrm{COHb})$, which reduces the amount of oxygen supplied by the blood. As a consequence, people suffer from tissue hypoxia at low exposure levels. At higher concentrations, carbon monoxide significantly decreases oxygen consumption by the brain, the heart, exercising skeletal muscle and developing foetuses (cf. Word Health Organization WHO [3]). Non-smokers in certain jobs can have long-term $\mathrm{COHb}$ concentrations up to $5 \%$, while $\mathrm{COHb}$ content in heavy cigarette smokers can be up to $10 \%$. Nonsmokers, the foetuses of non-smoking pregnant women and people with coronary artery disease should be protected in such way that the $\mathrm{COHb}$ level of $2.5 \%$ is not exceeded (cf. WHO [3]). This 
guideline can be met if a certain the $\mathrm{CO}$ concentration with respect to time is not exceeded. The comparison among WHO [3], USA [4], German [5] and Polish [6] recommendations is presented in the full text

Nieciecki and Gładyszewska-Fiedoruk [7] reported the human body's reactions to particular $\mathrm{CO}_{2}$ concentration values in the air. Below is listed the volume percentages and human organism reactions that may appear in different job conditions, selected from the work of Nieciecki and Gładyszewska-Fiedoruk [7]:

- $0.15 \%$ - sense of impure air and sense of stuffiness;

- $0.2 \%$ - weakened individuals that suffer from respiratory diseases may cough or sometimes suffer from syncope;

- $1 \%$-breath frequency is increased;

- $1.5 \%$ - mild metabolic stress appears after a longer time of respiration; this is the maximal tolerated concentration in submarines and space ships.

The volume percentage of $0.15 \%$ means $0.0015 \mathrm{~m}^{3}$ of $\mathrm{CO}_{2}$ or $1.5 \mathrm{dm}^{3}$ in $1 \mathrm{~m}^{3}$ of air.

The European Garage Equipment Association (EGEA) warns that harmful exhaust is emitted from even modern combustion engines. It publishes the following general recommendations [8]:

- Exposure to vehicle exhaust emissions indoors should be avoided whenever possible;

- If safety cannot be guaranteed, the workspace should be equipped with an exhaust extraction system to protect the workers against hazardous substances;

- Exhaust emissions should be captured at source, which means directly at the exhaust tailpipe. The exhaust nozzle or funnel should be designed so that $100 \%$ of the exhaust emissions can be captured;

- Exhaust extraction systems should work at vacuum gage pressure;

- The extraction volume should be at least $25 \%$ above the maximum emitted exhaust volume;

- The extraction system specification should accommodate the largest engine in use at the workplace.

The EGEA [8] recommends different extraction volume flow rates depending on engine volume and the type of service:

- $450 \mathrm{~m}^{3} / \mathrm{h}$ is needed for cars with up to 4 litre engines that are being serviced;

- $900 \mathrm{~m}^{3} / \mathrm{h}$ is needed for cars with up to 4 litre engines when exhaust tests are carried out;

- $1000 \mathrm{~m}^{3} / \mathrm{h}$ is needed for trucks with up to 16 litre engines that are being serviced;

- $1800 \mathrm{~m}^{3} / \mathrm{h}$ is needed for trucks with up to 16 litre engines when exhaust tests are carried out.

Ventilating or air conditioning systems are controlled by the value of indoor temperature or relative humidity. Although carbon dioxide is considered a pollutant and its gains are taken in consideration in air balance, its concentration is not controlled in ventilation systems (cf., e.g., [9]).

Carbon monoxide is much more harmful substance by far. However, there is no set concentration limit of this poisonous substance in ventilation system controllers. The general aim of the paper is to facilitate a change in attitude towards this issue, so that the concentrations carbon oxides, especially carbon monoxide, would be the desired values determined by the controllers of a ventilation system in any place where exhaust fumes are emitted. The particular goal is to convince each auto repair shop owner that ventilation system installation is a necessity.

\section{Materials and Methods}

The measurements were conducted in a three-place auto repair shop with a staff of four people. The building is located in a county town in the northeast part of Poland. It was constructed with perforated brick and insulated with Styrofoam. The shop is not ventilated with a stack effect nor with mechanical ventilation. The only form of ventilation is infiltration through the relatively large and unsealed doors. The window frames are made with Polyvinyl chloride (PVC). 
This one-week experiment is a part of an experiment series that was conducted in different seasons in one location. It was conducted in autumn, November 2018, which was during the heating season. For this reason, the garage door was opened only when a car was being driven in or out. A probe for carbon monoxide concentration measurement and another probe for carbon dioxide content measurement were placed $170 \mathrm{~cm}$ above the floor.

The maximum $8 \mathrm{~h}$ average was calculated from moving averages, calculated every hour from eight $1 \mathrm{~h}$ averages over a $24 \mathrm{~h}$ period

\section{The Results}

The recommended $\mathrm{CO}_{2}$ level (1000 ppm) was exceeded on 17 November for $3 \mathrm{~h}$ (from 11:00 to 13:00) with the maximal value at $2578.1 \mathrm{mg} / \mathrm{m}^{3}$. A greater concentration was recorded on 19 November for $2 \mathrm{~h}$ (8:00 and 9:00) at the maximal level of $2982.5 \mathrm{mg} / \mathrm{m}^{3}$. On 20-23 November, there were sporadically occurring $1 \mathrm{~h} \mathrm{CO} 2$ exceedances, whose concentration values reached up to 3264.4 $\mathrm{mg} / \mathrm{m}^{3}$.

In the case of carbon monoxide, the maximal measured value was $480.88 \mathrm{mg} / \mathrm{m}^{3}$ on 22 November at 9:32.

The short-term exposure limit, according to WHO recommendations [3], (100 mg/m³ per $15 \mathrm{~min})$ was exceeded twice. The first exceedance lasted $50 \mathrm{~min}$ on 22 November, between 8:57 and 9:47, with an average value of $212.07 \mathrm{mg} / \mathrm{m}^{3}$, the fifteen-minute means changes from $117.45 \mathrm{mg} / \mathrm{m}^{3}$ to 402.91 $\mathrm{mg} / \mathrm{m}^{3}$. The second time the limit was exceeded occurred $10 \mathrm{~h}$ later, i.e., between 19:22 and 19:42, with an average value of $112.04 \mathrm{mg} / \mathrm{m}^{3}$. The Polish regulation was exceeded the first time, coinciding with the first exceedance of the WHO recommendations. In the second case, the exceedance lasted $15 \mathrm{~min}$ from $19: 27$ to $19: 42$ at $119.02 \mathrm{mg} / \mathrm{m}^{3}$.

The $30 \mathrm{~min}$ exposure limit $\left(60 \mathrm{mg} / \mathrm{m}^{3}\right.$ in WHO recommendations [3]) was exceeded six times. The first exceedance occurred on 19 November and lasted from $17: 57$ to $18: 27$ at $64 \mathrm{mg} / \mathrm{m}^{3}$. The second case took place on 20 November from $18: 17$ to $19: 42$ at $68.88 \mathrm{mg} / \mathrm{m}^{3}$. The third one was measured on 21 November between 15:57 and $16: 27$ at $62.77 \mathrm{mg} / \mathrm{m}^{3}$. The last three non-fulfilments were on 22 November, between 8:47 and 10:52 at $142.03 \mathrm{mg} / \mathrm{m}^{3}$; between $11: 12$ and $11: 42$ at $64.03 \mathrm{mg} / \mathrm{m}^{3}$; and between 19:07 and 20:02 at $79.88 \mathrm{mg} / \mathrm{m}^{3}$.

The $1 \mathrm{~h}$ exposure was greater than WHO recommendations $\left(30 \mathrm{mg} / \mathrm{m}^{3}\right)$ in eight long-term periods. The first time occurred on $17 \mathrm{Nov}$ between 10:37 and $11: 52$ at $31.53 \mathrm{mg} / \mathrm{m}^{3}$. This was followed by Sunday, 18 November, which was a day off work. The second period started on 19 November at 17:02 and ended at 19:52 with an average concentration of $44.22 \mathrm{mg} / \mathrm{m}^{3}$. The three consecutive exceedances were recorded on the next day between $8: 57$ and $11: 27$ at $30.75 \mathrm{mg} / \mathrm{m}^{3}$; between 14:02 and $15: 37$ at $35.07 \mathrm{mg} / \mathrm{m}^{3}$; and between $17: 42$ and $21: 22$ at $51.80 \mathrm{mg} / \mathrm{m}^{3}$. The CO concentration was above the limit on 21 November between 14:52 and 17:42 at $45.04 \mathrm{mg} / \mathrm{m}^{3}$. The last two times the WHO recommendation was broken were on 22 November, between $8: 17$ and $12: 22$ at $92.74 \mathrm{mg} / \mathrm{m}^{3}$ and between 17:37 and 20:52 at $51.34 \mathrm{mg} / \mathrm{m}^{3}$. On November 23, no exceedance was recorded.

There was no exceedance in terms of the time-weighted average $\mathrm{CO}_{2}$ concentration. However, the time-weighted average $\mathrm{CO}$ concentration was too high in four consecutive days from 20 to 23 November.

\section{Conclusions}

The results of the measurements lead to the conclusion that working in this garage can threaten employees' health. The lack of any ventilation is not acceptable, and results in the nonfulfillment of WHO [3] recommendations on numerous occasions. What is worse, the regulations of the Ministry of Economy and Labour [10] were breached on four constitutive weekdays. Such situations originate from the lack of fulfilment of the guidelines of the European Garage Equipment Association [8].

So as to improve work conditions and save workers from exposure to poisonous carbon monoxide, the installation of an exhaust extraction system that satisfies EGEA indications is recommended. 
Author Contributions: A.G. and K.J. conceived and designed the experiments; K.J. performed the experiments; A.G. created the calculation algorithm; K.J. did the computations; A.G. and K.J. analysed the data and wrote the paper.

Acknowledgments: The paper was prepared at the Students' Scientific Society “Heat Engineer" at Bialystok University of Technology and was financed by this university.

Research was carried out at Bialystok University of Technology in the Department of HVAC Engineering as the project WZ/WBiIŚ/4/2019 which was subsidised by the Ministry of Science and the Higher Education Republic of Poland from the funding for statutory R\&D activities.

The paper was prepared using equipment which was purchased thanks to "INNO-EKO-TECH" Innovative Research and Didactic Centre for Alternative Energy Sources, Energy Efficient Construction and Environmental Protection-a project implemented by the Technical University of Bialystok (PB), co-funded by the European Union through the European Regional Development Fund under the Programme Infrastructure and Environment-and thanks to "Research on the efficacy of active and passive methods of improving the energy efficiency of the infrastructure with the use of renewable energy sources" - a project co-financed by the European Regional Development Fund under the Regional Operational Programme of the Podlaskie Voivodship for the years 2007-2013.

Conflicts of Interest: The founding sponsors had no role in the design of the study; in the collection, analyses, or interpretation of data; in the writing of the manuscript, and in the decision to publish the results.

\section{References}

1. Environment and Quality of Life. Guidelines for Ventilation Requirements in Buildings; Report No. 11; Commission of the European Communities Directorate General Information Market and Innovation Batiment Jean Monnet: Luxembourg, 1992.

2. Gładyszewska-Fiedoruk, K.; Nieciecki, M. Indoor air quality I a multi-Car garage. In Proceedings of the International Scientific Conference on Environmental and Climate Technologies (CONECT 2015), Riga, Latvia, 14-16 October 2015.

3. Air Quality Guidelines for Europe, Second ed.; European Series 91; WHO Regional Office for Europe Copenhagen: København, Denmark, 2000. Available online: http://www.euro.who.int/_data/assets/pdf_file/0005/74732/E71922.pdf (accessed on 12 March 2019).

4. ASHRAE Standard 62.1-2016, Ventilation for Acceptable Indoor Air Quality. Available online: https://ashrae.iwrapper.com/ViewOnline/Standard_62.1-2016 (accessed on 16 July 2018).

5. Deutsche Forschungsgemeinschaft, List of MAK and BAT Values 2017, Maximum Concentrations and Biological Tolerance Values at the Workplace. Available online: https://onlinelibrary.wiley.com/doi/pdf/10.1002/9783527812127.oth (accessed on 16 July 2018).

6. Regulation of the Minister of Labour and Social Policy (Republic of Poland) of 29 November 2002 on Maximum Permissible Concentration and Intensity of Agents Harmful to Health in the Working Environment (Dz. U. [Journal of Laws] of 2002, 217, Item 1833). Available online: http://dziennikustaw.gov.pl/du/2002/1833/D2002217183301.pdf (accessed on 12 July 2018).

7. Nieciecki, M.; Gładyszewska-Fiedoruk, K. A Pilot Study of Air in the Garage. Part 1. Introduction, COW 2012, 43, 300-305

8. Guidelines for the Reduction of Exposure to Hazardous Vehicle Exhaust Emissions, European Garage Equipment Association. Available online: https:/www.egea-association.eu/wpcontent/uploads/guidelines-vehicle-emissions-egea-2011.pdf (accessed on 17 July 2018).

9. Gładyszewska-Fiedoruk, K. Correlations of air humidity and carbon dioxide concentration in the kindergarten. Energy Build. 2013, 62, 45-50.

10. Regulation of Minister of Economy and Labour (Republic of Poland) of 10 October 2005 to Amend the Regulation on Maximum Permissible Concentration and Intensity of Agents Harmful to Health in the Working Environment (Dz.U. $2005 \mathrm{nr} 212$ poz. 1769). Available online: http://dziennikustaw.gov.pl/du/2005/1769/D2005212176901.pdf (accessed on 13 July 2018). 